\title{
EFFECT OF KAOLIN APPLICATIONS ON FRUIT SUNBURN, YIELD AND FRUIT QUALITY OF BALADY MANDARIN (Citrus reticulata, Blanco)
}

\author{
H.A. Ennab, S.A. El-Sayed and M.M.S. Abo El-Enin \\ Citrus Research Department, Hort. Res. Instit. ARC. Giza, Egypt.
}

Received: Jan. 22, 2017

Accepted: Feb. 12,2017

\begin{abstract}
Sunburn is a major problem caused by high temperature and direct solar radiation, which leads to significant economic losses in Balady mandarin yield. So, a field experiment was conducted during 2014 and 2015 seasons at a private orchard situated in Motobus, Kafr El-Sheikh governorate, Egypt, to study the effect of foliar spray of 0, 2, 3 and 4\% kaolin, twice or three times at May, June and July on sunburn percentage and fruit quality of Balady mandarin trees. The obtained results showed that, kaolin foliar applications were effective to control fruit sunburn as well as reducing severity percentage of sunburned fruits as compared to untreated trees. Moreover, Kaolin foliar application at three times was decreased leaf and fruit surface temperature especially at the concentrations of 3 and $4 \%$. In addition, kaolin treatments increased yield and improved fruit quality in terms of fruit size, diameter, weight, peel thickness and vitamin C. Kaolin foliar spray was raising fruit values of SSC\%, acidity and SSC/acid ratio compared to control trees, whereas there is no significant variation among kaolin concentrations on this variables. Therefore, it could be recommended that, spraying kaolin at 3 or $4 \%$ three times in summer months, because it had a positive effect on preventing fruit sunburn damage and improvement yield and fruit quality of Balady mandarin trees.
\end{abstract}

Key words: Citrus reticulata, Kaolin, Sunburn, Yield, Fruit quality, Solar injury

\section{INTRODUCTION}

Balady mandarin (Citrus reticulata, Blanco) occupies an important cultivar among the citrus grown in Egypt; due to it has good productive potential, easy peel and acceptable juice quality. In summer months, fruits of Balady mandarin exposed to heat stress caused by high temperature, together with direct solar radiation which causes sunburn in leaves and fruits. Sunburn (solar injury) causes important economic losses in a large number of fruit species such as apple, mango, grapevine, pomegranate and olive, as well as income loss to farmers (Schrader et al., 2003). In addition, with the continued depletion of the stratospheric ozone layer, the levels of UV-B radiation (280 to $320 \mathrm{~nm}$ ) reaching the earth's surface are increasing, together with global warming, indicate a probability of increasing incidence of sunburn in the future (Kerr and McElroy, 1993). Fruits are more prone to sunburn compared with the leaves, mainly because they are not capable with efficient mechanisms of using and/or dissipating solar radiation (Blanke and Lenz, 1989). As a result, fruit surface temperature may increase as high as 10 to $15^{\circ} \mathrm{C}$ higher than air temperature (Parchomchuk and Meheriuk, 1996). Therefore, the inadequacy of resistance mechanisms and the high susceptibility of fruit to sunburn would suggest the need for external intervention to suppress sunburn in fruit, and growers looking for the ways to escape from sunburn. Among the numerous culture practices developed to control sunburn in various crops using kaolin, particle film applications by spraying canopies with a suspension of different types of clay along with kaolin leaving a film on the leaves and fruits, which reflect sunlight this led to lower the temperature of leaf surface and fruits thereby reducing sunburn and improving fruit 
quality (Glenn and Puterka, 2005; Glenn, 2009 and Weerakkody et al., 2010). Kaolin (a clay) is a natural mineral which main constituent is kaolinite $\left(\mathrm{Al}_{2} \mathrm{Si}_{2} \mathrm{O}_{5}(\mathrm{OH})_{4}\right)$. Kaolin clay treatments have been successfully applied in different fruit species to minimized fruit sunburn and improve yield and fruit quality (Kerns and Wright, 2000; Colavita et al., 2011 and Alvarez et al., 2015).

So, the aim of this study is to investigate the effect of kaolin application in different concentrations and times on reducing sunburn and improving fruit quality of Balady mandarin trees.

\section{MATERIALS AND METHODS}

The present study was carried out during 2014 and 2015 seasons on 17 years old Balady mandarin trees (Citrus reticulata, Blanco) budded on sour orange (Citrus aurantium L.) rootstock, planted at $5 \times 5$ meter apart in a private orchard situated at Motobus, Kafr El-Sheikh governorate, Egypt. The trees received the same cultural practices usually done in this area. The soil texture was clay $(57.67 \%$ clay, $34.10 \%$ silt and $8.23 \%$ sand), $1.41 \%$ organic mater, $1.75 \mathrm{dSm}^{-1}$ an electrical conductivity and a $\mathrm{pH}$ of 8.21. The latitude and longitude of the experiment field are $31^{\circ} 27 \mathrm{~N}$ and $31^{\circ} 32 \mathrm{E}$. The metrological data of the studied period were presented in Fig (1). Forty two trees were selected as uniform as possible in size and load, and arranged in a randomized complete block design, each treatment replicated three times with two trees for each replicate. The experiment included 7 treatments as follow:

$\mathrm{T}_{1}$ Control (spray with tap water only)

$\mathrm{T}_{2}$ Spraying Kaolin at 2\% twice (15 May and 15 June)

$\mathrm{T}_{3}$ Spraying Kaolin at 2\% three times (15 May, 15 June and 15 July)

$\mathrm{T}_{4}$ Spraying Kaolin at 3\% twice (15 May and 15 June)

$\mathrm{T}_{5}$ Spraying Kaolin at 3\% three times (15 May, 15 June and 15 July)

$\mathrm{T}_{6}$ Spraying Kaolin at 4\% twice (15 May and 15 June)

$\mathrm{T}_{7}$ Spraying Kaolin at $4 \%$ three times (15 May, 15 June and 15 July)

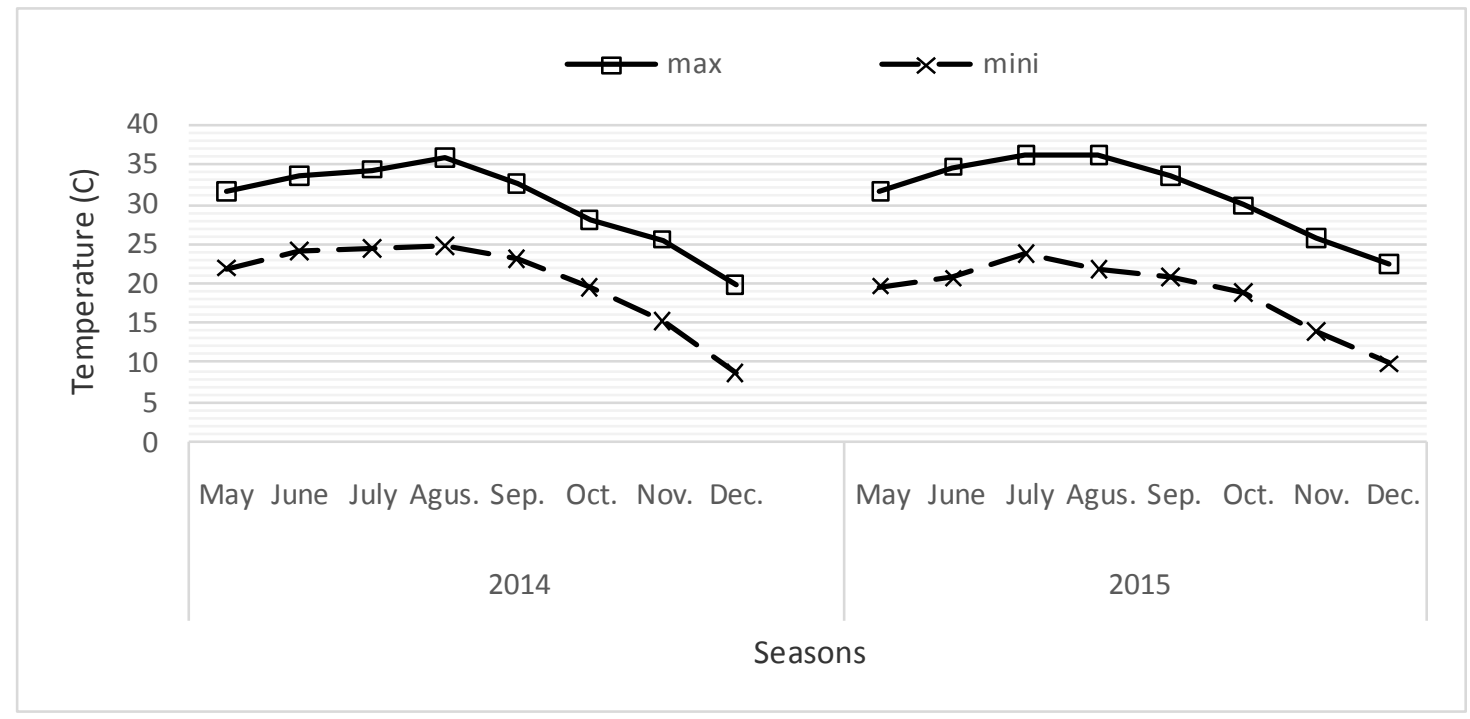

Fig. (1): Mean of maximum and minimum temperature data for Kafr El-Sheikh area during 2014 and 2015 seasons (source, meteorological station at Sakha 3107N latitude, $3057 \mathrm{E}$ longitude and with an elevation of about 6 meters above sea level, MSL). 


\section{The following data was recorded: \\ 1. Leaf and fruit surface temperature:}

Leaf and fruit surface temperature were measured on thirty fruit and leaves/tree on a hot months May, June and July on the sunny side of treated and control trees using an infra-red thermometer.

\section{Fruit sunburn percentage:}

Sunburned fruits were counted and sunburn percentage was calculated by using the follow equation:

Sunburn $\%=\frac{\text { No. of sunburned fruits }}{\text { Total No. of fruits }} \times 100$

\section{Severity \% of sunburned fruits:}

At harvest time (the first week of December), all sunburned fruit per tree were divided according to sun injuries to three categories, light (light bleaching), medium (fruit with tissue damage without necrosis) and high (dark necrotic areas accompanied by cell death) as showed in Fig. (2).

\section{Yield:}

At harvest time, average yield of fruits as $\mathrm{kg}$ per tree and fruit number/tree were calculated.

\section{Fruit quality:}

To determine fruit quality, 20 healthy fruits were taken at random from each tree at harvest time of both seasons and prepared for determination of physical and chemical fruit quality assessment according to (A.O.A.C., 1990). Fruit characters were fruit weight $(\mathrm{g})$, fruit size $\left(\mathrm{cm}^{3}\right)$, fruit height $(\mathrm{cm})$, and diameter $(\mathrm{cm})$, peel thickness (cm), fruit juice \%., soluble solids content (SSC) was determined by handly refractometer, total acidity was determined as citric acid, ascorbic acid as mg/100 $\mathrm{ml} /$ juice by using 2, 6 dichlorophenol indophenol and SSC/acid ratio was calculated.

\section{Statistical analysis}

The data were statistically analyzed as analysis of variance according to Snedecor and Cochran (1990). Duncan's multiple range test (Duncan, 1955) at 5\% level was used to compare the mean values.

\section{RESULTS AND DISCUSSION \\ 1. Leaf and fruit surface temperature:}

The results in Figures ( 3 and 4 ) indicated that kaolin foliar application significantly decreased leaf and fruit surface temperature compared to the control in both seasons. In this respect, leaf and fruit temperature were decreasing by increasing kaolin concentrations from 0 to $4 \%$ in both seasons. Moreover, fruit surface temperature recorded higher values than that recorded on leaf in both seasons. This result was true when kaolin sprayed twice at May and June or three times at May, June and July in both seasons. In addition, kaolin at 3 and $4 \%$ applied twice or three times $\left(T_{4}\right.$, $T_{5}, T_{6}$ and $T_{7}$ ) recorded the lowest values of leaf and fruit surface temperature without significant differences among them in both seasons. On the other hand, the highest temperature recorded in leaf and fruit surface obtained from control trees in both seasons. These results were agreement with those obtained by Gindaba and Wand (2007) on apple, Colavita et al., (2011) on pear and Chamchaiyaporn et al., (2013) on mango.

Generally, it is clear that increasing spraying concentrations with replicated three times had a positive effect on lowering temperature of leaves and fruits especially at the high concentrations of kaolin ( 3 and $4 \%$ ) compared to control treatment. The obtained reduction in leaf and fruit temperature as a result of kaolin application maybe due to an increased reflectance in direct solar radiation and the UV and visible range of wavelengths. Also, kaolin reduced both the light intensity and temperature of the leaves and fruits, resulting in less sunburn (Glenn, 
Ennab, et al.,

2012). Similar results were reported by Jifon and Syvertsen (2003) found that leaf temperature of grapefruit trees cv Ruby Red treated with $6 \%$ kaolin was lower than leaves of untreated trees. Melgarejo et al.,
(2004) using kaolin on pomegranate trees and found a reduction in leaf and fruit temperature as compared to non-treated ones.

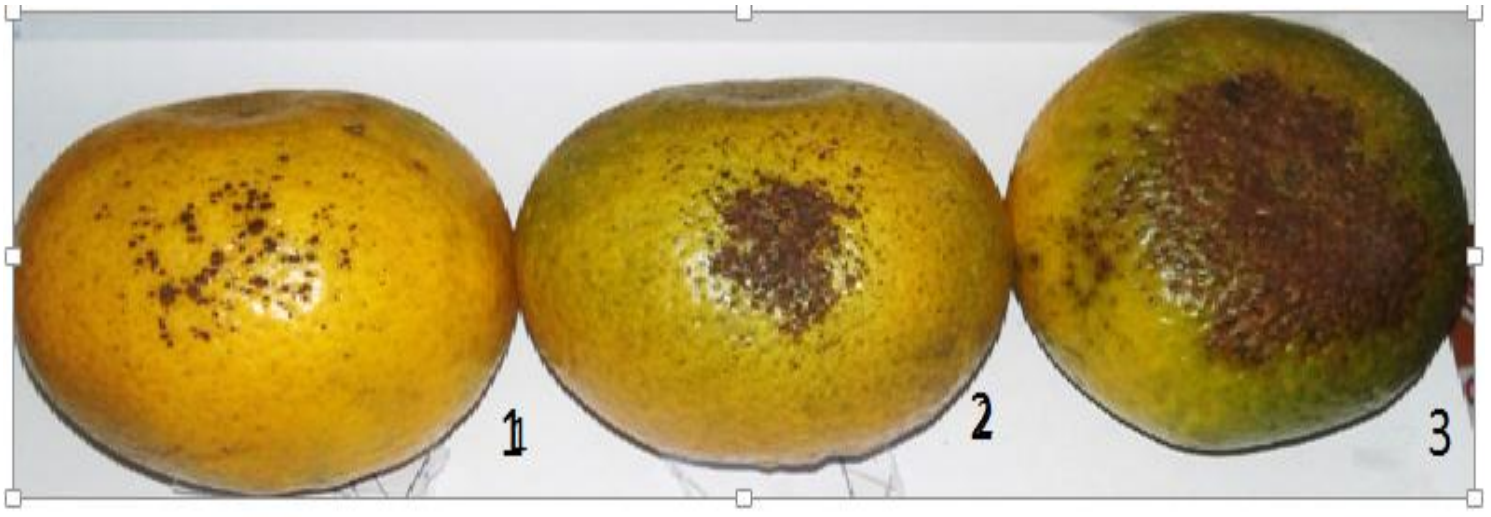

Fig. (2): Fruit sunburn severity adjective as light (1), medium (2) and high (3).

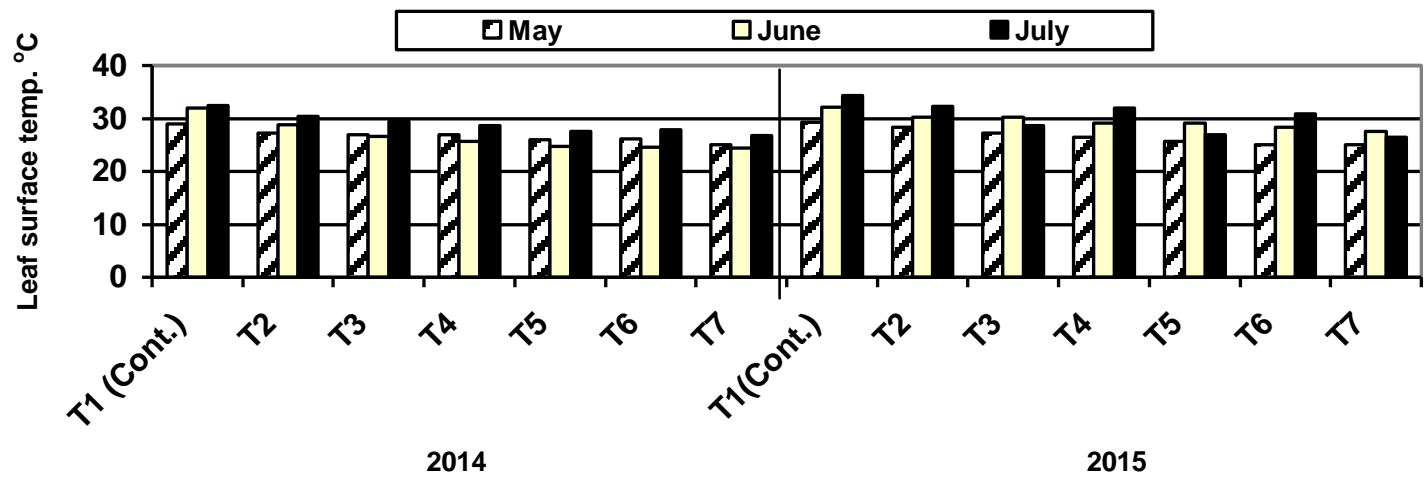

Fig. (3): Effect of kaolin application on leaf surface temperature of Balady mandarin trees during 2014 and 2015 seasons.

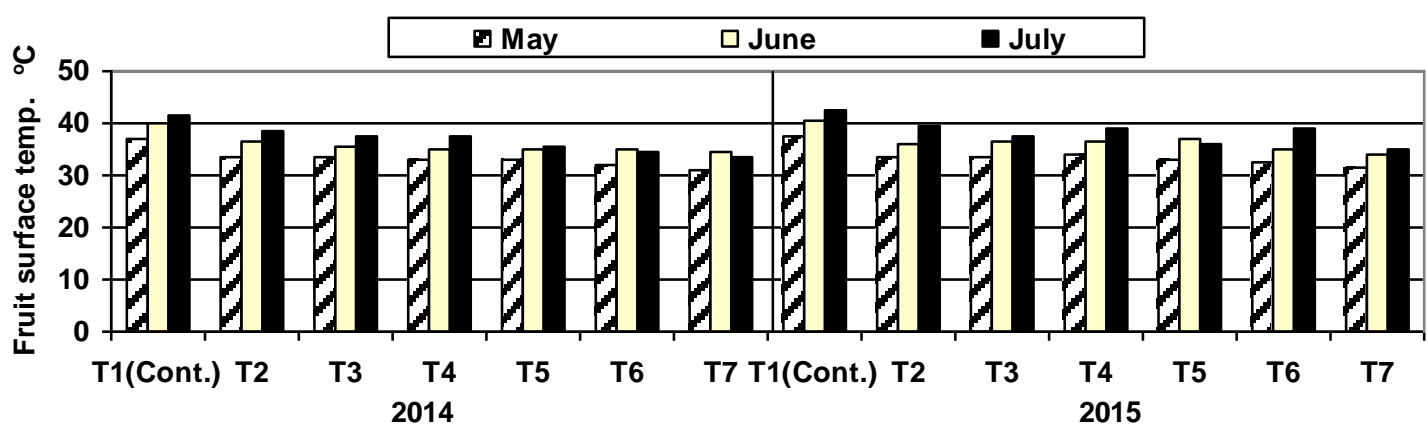

Fig. (4): Effect of kaolin application on fruit surface temperature of Balady mandarin trees during 2014 and 2015 seasons. 


\section{Fruit sunburn percentage:}

The results in Table (1) and Fig. (5) indicated that, kaolin foliar sprays markedly led to decreased sunburn percentage in fruits of Balady mandarin trees in both seasons. This reduction was proportional to kaolin concentrations. The differences were significant among treatments in both seasons. In this respect, control treatment $\left(T_{1}\right)$ gave the highest values of sunburn percentage (20.6 and 17.8\%) in both seasons, respectively. In contrast, the lowest values of sunburn percentage was observed in kaolin sprays at $4 \%$ three times $\left(T_{7}\right)$ with a sunburn percentage of 7.3 and $6.2 \%$ in both seasons. These results were similar to those obtained by Yazici and Kaynak (2009) on pomegranate, Colavita et al., (2011) on pear and Abd Alla et al., (2013) on mango. In this respect, Melgarejo et al., (2004) found that spraying pomegranate fruits with kaolin decreased sunburn percentage from $21.9 \%$ to $9.4 \%$.

Generally, sunburn percentage of Balady mandarin fruits was significantly decreased by using kaolin foliar sprays compared to control which sprayed with tap water in both seasons. Spraying kaolin at $4 \%$ three times in summer months showed to be the superior one in reducing sunburn percentage as compared with control and other treatments in both seasons. These results are in harmony with those obtained by Chabbal et al., (2014) and Hegazi et al., (2014) they found that, kaolin applied at 4 and $5 \%$ reduced sunburn $\%$ on Satsuma mandarin and pomegranate trees. Such reduction in sunburn percentage could be attributed to reduced heat stress and lowering fruit surface temperature. This conclusion came true with our results in Fig (4) and those obtained by Glenn et al., (2002) and Colavita et al., (2011) they reported that, foliar application of kaolin was effective in reducing fruit surface temperature and prevents sunburn in apple and pear fruits.

\section{Severity $\%$ of sunburned fruits:}

Data presented in Table (1) showed that, sunburned fruits per tree was classified three categories into light (light bleaching), medium (fruit with tissue damage without necrosis) and high (dark necrotic areas accompanied by cell death). The results cleared that, kaolin foliar spray significantly reduced sun injuries on sunburned fruits of Balady mandarin trees in both seasons. Spraying kaolin at 3 and $4 \%$ three times $\left(T_{5}\right.$ and $T_{7}$ ) reduced sun injuries in light and high categories compared with control and other treatments. The highest sun injuries recorded on sunburned fruits harvested from control treatment $\left(T_{1}\right)$ in light and high categories in both seasons. Kaolin foliar application had no significant effect on medium category in both seasons. These results were in agreement with those obtained by Weerakkody et al., (2010) and Vatandoost et al., (2014). Also, Glenn et al., (2002) revealed that, applications of kaolin at 45 and $56 \mathrm{~kg} / \mathrm{ha}^{-1}$ in concentrations of 3 and $6 \%$ every 3 weeks reduced solar injury in some apple cultivars in different locations.

Table (1): Effect of foliar application of kaolin on sunburn and severity percentages of Balady mandarin trees during 2014 and 2015 seasons.

\begin{tabular}{|l|c|c|c|c|c|c|c|c|}
\hline \multirow{2}{*}{ Treatments } & \multicolumn{2}{|c|}{$\begin{array}{c}\text { Sunburn } \\
\text { \% }\end{array}$} & \multicolumn{6}{|c|}{ Severity \% of sunburned fruit } \\
\cline { 2 - 9 } & 2014 & 2015 & Light & Medium & High & Light & Medium & High \\
\hline $\mathrm{T}_{1}$ (Cont.) & $20.6 \mathrm{a}$ & $17.8 \mathrm{a}$ & $11.0 \mathrm{~d}$ & $33.2 \mathrm{~b}$ & $55.8 \mathrm{a}$ & $9.2 \mathrm{~d}$ & $45.9 \mathrm{a}$ & $44.9 \mathrm{a}$ \\
$\mathrm{T}_{2}$ & $13.2 \mathrm{~b}$ & $10.6 \mathrm{~b}$ & $43.2 \mathrm{c}$ & $36.3 \mathrm{ab}$ & $20.5 \mathrm{~b}$ & $45.4 \mathrm{c}$ & $40.7 \mathrm{ab}$ & $14.9 \mathrm{~b}$ \\
$\mathrm{~T}_{3}$ & $12.5 \mathrm{~b}$ & $10.5 \mathrm{~b}$ & $48.5 \mathrm{~b}$ & $37.4 \mathrm{a}$ & $14.1 \mathrm{c}$ & $47.9 \mathrm{abc}$ & $38.1 \mathrm{~b}$ & $15.6 \mathrm{~b}$ \\
$\mathrm{~T}_{4}$ & $13.1 \mathrm{~b}$ & $9.7 \mathrm{bc}$ & $42.5 \mathrm{c}$ & $35.6 \mathrm{ab}$ & $21.8 \mathrm{~b}$ & $44.7 \mathrm{c}$ & $40.5 \mathrm{ab}$ & $14.5 \mathrm{~b}$ \\
$\mathrm{~T}_{5}$ & $9.7 \mathrm{c}$ & $8.7 \mathrm{~cd}$ & $50.4 \mathrm{ab}$ & $36.9 \mathrm{ab}$ & $12.7 \mathrm{c}$ & $49.8 \mathrm{ab}$ & $38.3 \mathrm{~b}$ & $11.8 \mathrm{bc}$ \\
$\mathrm{T}_{6}$ & $9.3 \mathrm{c}$ & $7.9 \mathrm{~d}$ & $42.7 \mathrm{c}$ & $35.3 \mathrm{ab}$ & $21.9 \mathrm{~b}$ & $47.4 \mathrm{bc}$ & $38.3 \mathrm{~b}$ & $14.3 \mathrm{~b}$ \\
$\mathrm{~T}_{7}$ & $7.3 \mathrm{~d}$ & $6.2 \mathrm{e}$ & $51.6 \mathrm{a}$ & $37.9 \mathrm{a}$ & $10.5 \mathrm{c}$ & $51.1 \mathrm{a}$ & $39.3 \mathrm{~b}$ & $9.5 \mathrm{c}$ \\
\hline
\end{tabular}

Means followed by different letter are significantly different within columns by Duncan's multiple range test, $P \leq 0.05$. 
Ennab, et al.,

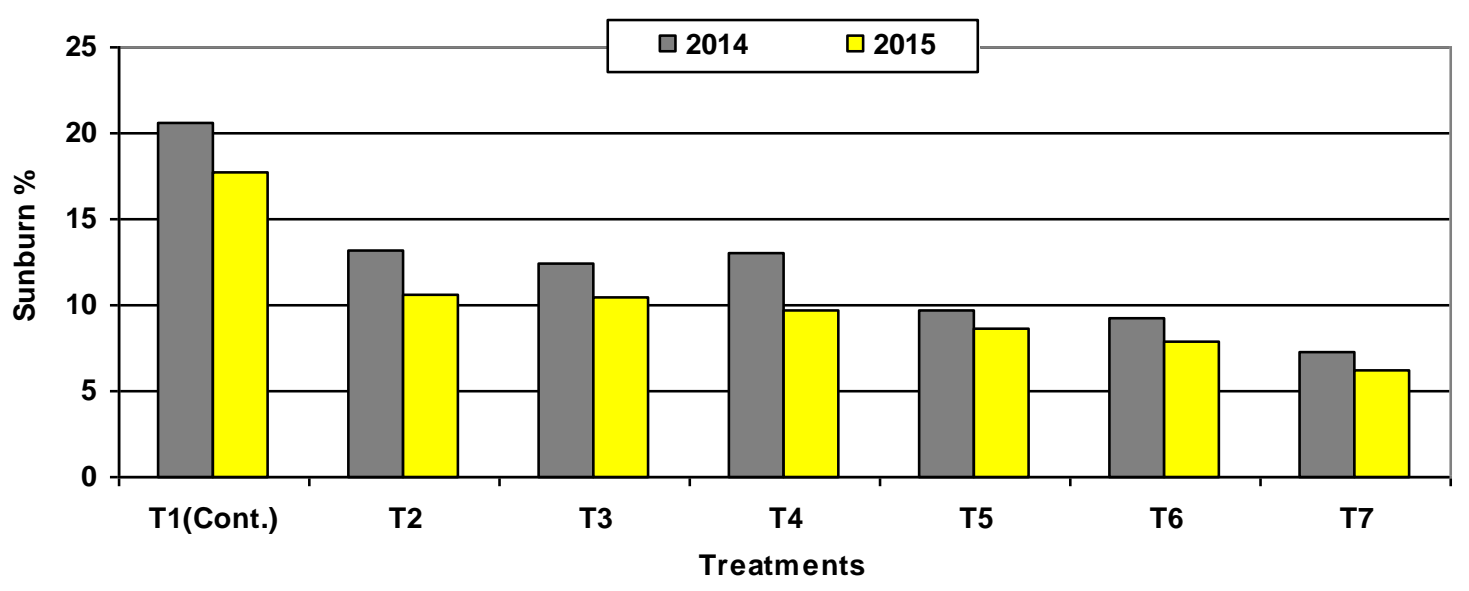

Fig. (5): Effect of kaolin application on sunburn percentage of Balady mandarin trees during 2014 and 2015 seasons.

\section{Yield and its components:}

Data in Table (2) showed that, yield as number of fruits per tree and weight $(\mathrm{kg} / \mathrm{tree})$ of Balady mandarin trees was significantly increased by all kaolin treatments comparing with control during 2014 and 2015 seasons. Also, yield in the first season was higher than the second one. In this respect, the highest yield was observed with kaolin foliar application of $4 \%$ twice or three times $\left(T_{6}\right.$ and $\mathrm{T}_{7}$ ) and kaolin concentration at $3 \%$ three times $\left(T_{5}\right)$ without significant differences among them in both seasons. However, trees sprayed with tap water and kaolin at $2 \%$ twice $\left(T_{1}\right.$ and $\left.T_{2}\right)$ gave the lowest yield as number of fruits per tree and weight $\mathrm{kg} /$ tree compared to other treatments in both seasons. These results were in agreement with those obtained by Kerns and Wright (2000) and Lombardini et al., (2005). In this respect, Abdel Ghani et al., (2013) concluded that, kaolin foliar spray at 5\% significantly increased yield as number of fruits per tree or weight $(\mathrm{kg})$ of Aggezi and Picual olive compared to foliar spray with calcium carbonate (5\%) and tap water.

As for fruit weight, it is clear from data in Table (2) that, fruit weight was positively affected by kaolin foliar applications comparing with the control. Highest fruit weight was obtained from trees sprayed with kaolin at $4 \%$ three times $\left(T_{7}\right)$ followed in a descending order by $4 \%$ twice and $3 \%$ three times $\left(T_{6}\right.$ and $\left.T_{5}\right)$ as compared with control and other treatments in both seasons. These results are similar to those obtained by Schupp et al., (2002), Aly et al., (2010) and Hegazi et al., (2014).

\section{Fruit quality:}

About the response of fruit quality of Balady mandarin to foliar application of kaolin particles in different concentrations and times, data in Table (3) show a significant differences among treatments in both seasons as for physical fruit quality i.e. fruit size, diameter, peel thickness and juice weight $\%$ while the differences were not significant as for fruit height in 2014 and 2015 seasons. Spraying kaolin at $4 \%$ three times $\left(T_{7}\right)$ gave the highest significant values of fruit size, diameter and peel thickness followed by kaolin at $3 \%$ and $2 \%$ sprayed three times $\left(T_{6}\right.$ and $\left.T_{5}\right)$ compared with the control treatment in both seasons. These results are in accordance with those obtained by Palitha et al., (2010), Abd-Allah et al., (2013) and Hegazi et al., (2014).

Also data in Table (4) cleared that, soluble solids content (SSC) and SSC/acid ratio were significantly lower in fruits harvested from $\left(T_{1}\right)$ control trees than those 
recorded on all kaolin treatments in both seasons. Kaolin treatments gave approximately the same values of SSC and $\mathrm{SSC} /$ acid ratio without significant differences among them in both seasons. Similarly, acidity was slightly increased by kaolin treatments without significant differences among them compared to control in both seasons. Moreover, spraying kaolin at different concentrations tended to significantly increased vitamin C comparing with the control in both seasons. Generally, kaolin treatments enhanced chemical fruit quality in terms of SSC, acidity and $\mathrm{SSC} /$ acid ratio as compared with control treatment, whereas there is no significant variation among kaolin concentrations on chemical fruit quality. Similar results were obtained by Gindaba and Wand (2007) and Chabbal et al., (2014).

Table (2): Effect of foliar application of kaolin on yield and fruit weight of Balady mandarin trees during 2014 and 2015 seasons.

\begin{tabular}{|l|l|l|l|l|l|l|}
\hline \multirow{2}{*}{ Treatments } & \multicolumn{4}{c|}{ Yield/tree } & \multicolumn{2}{c|}{ Fruit weight (g) } \\
\cline { 2 - 7 } & \multicolumn{2}{|c|}{ Fruit number } & \multicolumn{2}{c|}{$\mathrm{kg}$} & \multicolumn{2}{c|}{} \\
\cline { 2 - 7 } & 2014 & 2015 & 2014 & 2015 & 2014 & 2015 \\
\hline $\mathrm{T}_{1}$ (Cont.) & $461.5 \mathrm{~d}$ & $370.4 \mathrm{~b}$ & $57.0 \mathrm{e}$ & $47.8 \mathrm{~d}$ & $122.9 \mathrm{c}$ & $129.0 \mathrm{~d}$ \\
$\mathrm{~T}_{2}$ & $481.8 \mathrm{~cd}$ & $383.6 \mathrm{ab}$ & $59.3 \mathrm{de}$ & $49.7 \mathrm{~cd}$ & $123.1 \mathrm{c}$ & $129.5 \mathrm{~d}$ \\
$\mathrm{~T}_{3}$ & $511.7 \mathrm{~b}$ & $410.3 \mathrm{a}$ & $64.2 \mathrm{c}$ & $53.7 \mathrm{~b}$ & $125.5 \mathrm{bc}$ & $131.0 \mathrm{~d}$ \\
$\mathrm{~T}_{4}$ & $492.5 \mathrm{bc}$ & $371.4 \mathrm{~b}$ & $61.4 \mathrm{~d}$ & $51.1 \mathrm{bc}$ & $124.6 \mathrm{c}$ & $137.5 \mathrm{c}$ \\
$\mathrm{T}_{5}$ & $5436 \mathrm{a}$ & $401.8 \mathrm{a}$ & $68.2 \mathrm{~b}$ & $57.3 \mathrm{a}$ & $125.4 \mathrm{bc}$ & $142.6 \mathrm{~b}$ \\
$\mathrm{~T}_{6}$ & $534.2 \mathrm{a}$ & $411.1 \mathrm{a}$ & $68.0 \mathrm{~b}$ & $57.7 \mathrm{a}$ & $127.3 \mathrm{~b}$ & $140.5 \mathrm{bc}$ \\
$\mathrm{T}_{7}$ & $542.4 \mathrm{a}$ & $406.7 \mathrm{a}$ & $71.6 \mathrm{a}$ & $59.9 \mathrm{a}$ & $132.1 \mathrm{a}$ & $147.6 \mathrm{a}$ \\
\hline
\end{tabular}

Means followed by different letter are significantly different within columns by Duncan's multiple range test, $\mathrm{P} \leq 0.05$.

Table (3): Effect of foliar application of kaolin on physical fruit quality of Balady mandarin trees during 2014 and 2015 seasons.

\begin{tabular}{|c|c|c|c|c|c|}
\hline Treatments & $\begin{array}{l}\text { Fruit } \\
\text { size } \\
\left(\mathrm{cm}^{3}\right)\end{array}$ & $\begin{array}{c}\text { Fruit } \\
\text { height } \\
(\mathrm{cm})\end{array}$ & $\begin{array}{c}\text { Fruit } \\
\text { diameter } \\
(\mathrm{cm})\end{array}$ & $\begin{array}{c}\text { Peel } \\
\text { thickness } \\
(\mathrm{cm})\end{array}$ & $\begin{array}{c}\text { Juice } \\
\text { weight } \\
(\%)\end{array}$ \\
\hline \multicolumn{6}{|c|}{2014 season } \\
\hline $\mathrm{T}_{1}$ (Cont.) & $135.4 \mathrm{c}$ & $5.0 \mathrm{a}$ & $6.3 \mathrm{e}$ & $0.29 d$ & $41.9 \mathrm{~b}$ \\
\hline $\mathrm{T}_{2}$ & $135.5 \mathrm{c}$ & $5.0 \mathrm{a}$ & $6.3 \mathrm{e}$ & $0.32 \mathrm{~cd}$ & $42.1 \mathrm{~b}$ \\
\hline $\mathrm{T}_{3}$ & $136.6 \mathrm{bc}$ & $5.2 \mathrm{a}$ & $6.4 \mathrm{de}$ & $0.33 \mathrm{~cd}$ & $42.3 a b$ \\
\hline $\mathrm{T}_{4}$ & $136.6 \mathrm{c}$ & $5.1 \mathrm{a}$ & $6.6 \mathrm{~cd}$ & $0.34 \mathrm{bc}$ & $42.7 \mathrm{ab}$ \\
\hline $\mathrm{T}_{5}$ & $136.7 \mathrm{bc}$ & $5.2 \mathrm{a}$ & $6.9 \mathrm{~b}$ & $0.38 a b$ & $42.8 \mathrm{ab}$ \\
\hline $\mathrm{T}_{6}$ & $135.9 \mathrm{~b}$ & $5.2 \mathrm{a}$ & $6.8 \mathrm{bc}$ & $0.34 \mathrm{bc}$ & $42.5 \mathrm{ab}$ \\
\hline $\mathrm{T}_{7}$ & $136.5 \mathrm{a}$ & $5.3 \mathrm{a}$ & $7.3 \mathrm{a}$ & $0.39 \mathrm{a}$ & $43.3 \mathrm{a}$ \\
\hline \multicolumn{6}{|c|}{2015 season } \\
\hline $\mathrm{T}_{1}$ (Cont.) & $140.8 \mathrm{~d}$ & $5.1 \mathrm{a}$ & $6.2 \mathrm{e}$ & $0.27 \mathrm{~d}$ & $42.0 \mathrm{~b}$ \\
\hline $\mathrm{T}_{2}$ & $141.9 \mathrm{~d}$ & $5.2 \mathrm{a}$ & $6.4 \mathrm{de}$ & $0.31 \mathrm{c}$ & $42.6 \mathrm{ab}$ \\
\hline $\mathrm{T}_{3}$ & $143.2 \mathrm{~d}$ & $5.3 \mathrm{a}$ & $6.5 \mathrm{~cd}$ & $0.32 b c$ & $42.9 \mathrm{a}$ \\
\hline $\mathrm{T}_{4}$ & $149.7 \mathrm{c}$ & $5.3 \mathrm{a}$ & $6.7 \mathrm{c}$ & $0.33 b$ & $42.6 \mathrm{ab}$ \\
\hline $\mathrm{T}_{5}$ & $155.0 \mathrm{~b}$ & $5.4 \mathrm{a}$ & $7.2 \mathrm{~b}$ & $0.37 \mathrm{a}$ & $42.8 \mathrm{a}$ \\
\hline $\mathrm{T}_{6}$ & $151.5 \mathrm{C}$ & $5.5 \mathrm{a}$ & $6.7 \mathrm{c}$ & $0.34 \mathrm{~b}$ & $42.8 \mathrm{a}$ \\
\hline $\mathrm{T}_{7}$ & $162.9 \mathrm{a}$ & $5.5 \mathrm{a}$ & $7.6 \mathrm{a}$ & $0.38 a$ & $43.2 \mathrm{a}$ \\
\hline
\end{tabular}

Means followed by different letter are significantly different within columns by Duncan's multiple range test, $P \leq 0.05$. 
Ennab, et al.,

Table (4): Effect of foliar application of kaolin on chemical fruit quality of Balady mandarin trees during 2014 and 2015 seasons.

\begin{tabular}{|l|c|c|c|c|c|c|c|c|}
\hline \multirow{2}{*}{ Treatments } & \multicolumn{2}{|c|}{$\begin{array}{c}\text { SSC } \\
\text { (\%) }\end{array}$} & \multicolumn{2}{c|}{$\begin{array}{c}\text { Acidity } \\
(\%)\end{array}$} & \multicolumn{2}{c|}{$\begin{array}{c}\text { SSC/acid } \\
\text { (ratio) }\end{array}$} & \multicolumn{2}{c|}{$\begin{array}{c}\text { Vitamin C } \\
\text { (mg/100 ml. juice) }\end{array}$} \\
\cline { 2 - 8 } & 2014 & 2015 & 2014 & 2015 & 2014 & 2015 & 2014 & 2015 \\
\hline $\mathrm{T}_{1}$ (Cont.) & $11.2 \mathrm{c}$ & $11.6 \mathrm{~d}$ & $1.05 \mathrm{c}$ & $1.10 \mathrm{a}$ & $10.6 \mathrm{c}$ & $10.5 \mathrm{c}$ & $39.2 \mathrm{c}$ & $40.3 \mathrm{~d}$ \\
$\mathrm{~T}_{2}$ & $12.4 \mathrm{~b}$ & $12.4 \mathrm{bc}$ & $1.10 \mathrm{~b}$ & $1.11 \mathrm{a}$ & $11.3 \mathrm{ab}$ & $11.1 \mathrm{ab}$ & $43.8 \mathrm{~b}$ & $45.8 \mathrm{bc}$ \\
$\mathrm{T}_{3}$ & $12.7 \mathrm{ab}$ & $12.6 \mathrm{ab}$ & $1.12 \mathrm{a}$ & $1.11 \mathrm{a}$ & $11.3 \mathrm{ab}$ & $11.3 \mathrm{ab}$ & $45.5 \mathrm{ab}$ & $46.4 \mathrm{abc}$ \\
$\mathrm{T}_{4}$ & $12.7 \mathrm{ab}$ & $12.3 \mathrm{bc}$ & $1.11 \mathrm{ab}$ & $1.10 \mathrm{a}$ & $11.3 \mathrm{ab}$ & $11.1 \mathrm{ab}$ & $43.7 \mathrm{~b}$ & $44.8 \mathrm{c}$ \\
$\mathrm{T}_{5}$ & $12.5 \mathrm{~b}$ & $12.7 \mathrm{ab}$ & $1.12 \mathrm{a}$ & $1.11 \mathrm{a}$ & $11.1 \mathrm{~b}$ & $11.4 \mathrm{ab}$ & $45.6 \mathrm{ab}$ & $46.6 \mathrm{ab}$ \\
$\mathrm{T}_{6}$ & $12.5 \mathrm{~b}$ & $12.1 \mathrm{c}$ & $1.12 \mathrm{a}$ & $1.10 \mathrm{a}$ & $11.1 \mathrm{~b}$ & $11.0 \mathrm{~b}$ & $44.8 \mathrm{ab}$ & $45.8 \mathrm{bc}$ \\
$\mathrm{T}_{7}$ & $12.9 \mathrm{a}$ & $12.9 \mathrm{a}$ & $1.12 \mathrm{a}$ & $1.12 \mathrm{a}$ & $11.5 \mathrm{a}$ & $11.5 \mathrm{a}$ & $46.5 \mathrm{a}$ & $48.1 \mathrm{a}$ \\
\hline
\end{tabular}

Means followed by different letter are significantly different within columns by Duncan's multiple range test, $\mathrm{P} \leq 0.05$.

\section{CONCLUSION}

From the obtained results, it could be concluded that spraying kaolin at 3 and $4 \%$ three times in summer months had a positive effect on preventing fruit sunburn damage and improvement yield and fruit quality of Balady mandarin trees.

\section{REFERENCES}

Abd Allah, A.S.E., E. Abd El-Razek and M.M.S. Saleh (2013). Effect of sun-block materials on preventing sunburn injury of Keitt mango fruits. J. Appl. Sci. Res., 9(1): $567-571$.

Abdel Ghani, N.A., M.A. Galal, M.E. ElSayed, S.M. El-Marsafawy and M.A. Omran (2013). Effect of spraying kaolin and calcium carbonate on the productivity of Aggezi and Picual olive cvs. J. Plant Production, Mansoura Univ., 4(7):1035 - 1050.

Alvarez, H.L., C.M. DiBella., G.M. Colavita., P. Oricchio and J. Strachnoy (2015). Comparative effects of kaolin and calcium carbonate on apple fruit surface temperature and leaf net $\mathrm{CO}_{2}$ assimilation. Journal of Applied Horticulture, 17(3): 176 - 180.

Aly, M., N. Abd El-Megeed and R.M. Awad (2010). Reflective particle films affected on, sunburn, yield, mineral composition and fruit maturity of Anna apple (Malus domestica) trees. Res. J. Agric. \& Biol. Sci., 6(1): $84-92$.

Association of official Agriculture chemists (1990). Official and tentative methods of analysis, (the AOAC $13^{\text {th }}$ ed. Washington, D. C., USA.).

Blanke, M.M. and F. Lenz (1989). Fruit photosynthesis. Plant, Cell and Environ. 12(1): $31-46$.

Chabbal, M.D., A.B. Piccoli., G.C. Martinez., M.M. Avanza., S.M. Mazza and V.A. Rodriguez (2014). Kaolin applications to control sunburn in 'Okitsu' mandarin. Cultivos Tropicales, 35(1): $50-56$.

Chamchaiyaporn, T., K. Jutamanee, P. Kasemsap, P. Vaithanomsat and C. Henpitak (2013). Effects of kaolin clay coating on mango leaf gas exchange, fruit yield and quality. Kasetsart J. (Nat. Sci.) 47:479 - 491.

Colavita, G.M., V. Blackhall and S. Valdez (2011). Effect of kaolin particle films on the temperature and solar injury of pear fruits. Acta Hort., 909:609 - 616.

Duncan, D.B. (1955). Multiple ranges and multiple F-tests. Biometrics, 11:1 - 42.

Gindaba, J. and S.J. Wand (2007). Do fruit sunburn control measures affect leaf photosynthetic rate and stomatal conductance in Royal Gala apple? Environmental and Experimental Botany 59:160 - 165 . 
Glenn, D.M. (2009). Particle film mechanisms of action that reduce the effect of environmental stress in Empire Apple. J. Amer. Soc. Hort. Sci. 134(3):314 - 321.

Glenn, D.M. (2012). The mechanisms of plant stress mitigation by kaolin-based particle films and applications in horticultural and agricultural crops. HortScience 47(6):710 - 711.

Glenn, D.M., E. Prado, A. Erez, G.M. Ferson and G.J. Puterka (2002). A reflective processed kaolin particle film affects fruit temperature, radiation reflection and solar injury in apple. J. Amer. Soc. Hort. Sci. 126(2):188 - 193.

Glenn, D.M. and G.J. Puterka (2005). Particle films: A new technology for agriculture. Hort. Rev. (Amer. Soc. Hort. Sci.) $31: 1-44$.

Hegazi, A., N. R. Samra, E.E.T. El-Baz, B. M. Khalil and M.S. Gawish (2014). Improving fruit quality of Manfalouty and Wonderful pomegranates by using bagging and some spray treatments with gibberellic acid, calcium chloride and kaolin. J. Plant Production, Mansoura Univ., 5 (5): 779 - 792.

Jifon, J. L. and J. P. Syvertsen (2003). Kaolin particle film application can increase photosynthesis and water use efficiency of Ruby Red grapefruit leaves. J. Amer. Soc. Hort. Sci., 128:107 - 112.

Kerns, D.L. and G.C. Wright (2000). Protective and yield enhancement qualities of kaolin on lemons. Citrus and Deciduous Fruit and Nut Research Report(publ. az1178), College of Agriculture and Life Sciences, the University of Arizona, Tucson, Arizona, 85721.

Kerr, J.B. and C.T. McElroy (1993). Evidence for large upward trends of UV$B$ radiation linked to ozone depletion. Science, 262: 1032 - 1034.

Lombardini, L., M.K. Harris and D.M. Glenn (2005). Effects of particle film application on leaf gas exchange, water relations, nut yield, and insect populations in mature pecan trees. HortScience 40(5):1376 - 1380 .

Melgarejo, P., J.J. Martinez, F. Hernandez, R. Martinez-Font, P. Barrows and A. Erez (2004). Kaolin treatment to reduce pomegranate sunburn. Scientia Horticulture, 100(1 - 4): $349-353$.

Palitha, W.J., M. Magdalena and J. Rogers (2010). The effect of maturity, sunburn and application of sunscreen on the internal and external qualities of pomegranate fruit grown in Australia. Scientia Hort., 124: $57-61$.

Parchomchuk, P. and M. Meheriuk (1996). Orchard cooling with pulsed over tree irrigation to prevent solar injury and improve fruit quality of 'Jonagold' apples. HortScience, 31(5): $802-804$.

Schrader, L., J. Zhang and J. Sun (2003). Environmental stress that caused sunburn of apple. Acta Hort., 618:397 405.

Schupp, J.R., E. Fallahi and I.J. Chun (2002). Effect of particle film on fruit sunburn, maturity and quality of Fuji and Honeycrisp apples. HorTechnology 12(1):87 - 90 .

Snedecor, G.W. and W.G. Cochran (1990). Statistical methods. 7th Ed. lowa State Univ. Press. Ames., lowa, USA, p. 593.

Vatandoost, S., G.H. Davarynejad and A. Tehranifar (2014). Would kaolin particle film avoid sunburn in Ardestani pomegranate. Advances in Environmental Biology, 8(12): $607-610$.

Weerakkody, P., J. Jobling, M.M. Infante and G. Rogers (2010). The effect of maturity, sunburn and the application of sunscreens on the internal and external qualities of pomegranate fruit grown in Australia. Scientia Horticulturae 124:57 61.

Yazici, K. and L. Kaynak (2009). Effects of kaolin and shading treatments on sunburn on fruit of Hicaznar cultivar of pomegranate (Punica granatum L. CV. Hicaznar). Acta Horticulture 818:167 174. 


\section{Ennab, et al.,}

تأثير إضافة الكاولين على لفحة الثمس و المحصول و جودة ثمار اليوسفي البلاي

حسن أبو القتوح عناب و سمية احمد السيذ و محمد محمد سعد أبو العينين

قسم الموالح - معهد بحوث البساتين - مركز البحوث الزراعية- الجيزة- مصر مئه

الملخص العربي

لفحة الثمس مشكلة كبيرة سببها إرتفاع درجات الحرارة و الإثعاع الثمسي المباشر، الأمر الذى يؤدى إلى إثى خسائر إقتصادية كبيرة في محصول اليوسفي البلدي ـ لذلك أجريت تجربـة حقلية خلال عامي 2014 و 2015 في مزرعة خاصة بمركز مطوبس، محافظة كفر الثيخ مصر • و ذللك لدراسة تأثير رش الكاولين بتركيزات 0، 2،

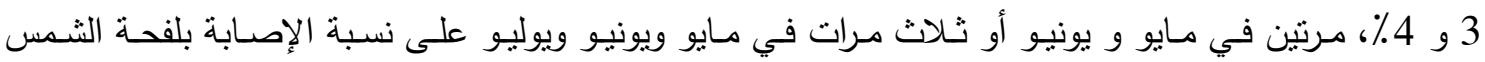
والمحصول وجودة الثمار في أشجار اليوسفي البلدي. وأوضحت النتائج أن إستخدام الكاولين رشا على أشجاراليوسفى البلدي أدى إلى خفض النى النسبة المئوية للإصابة

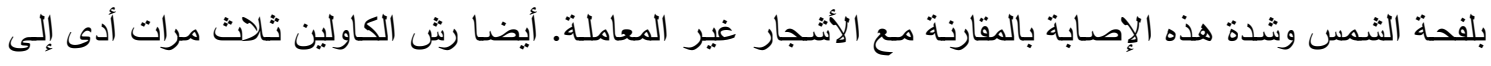

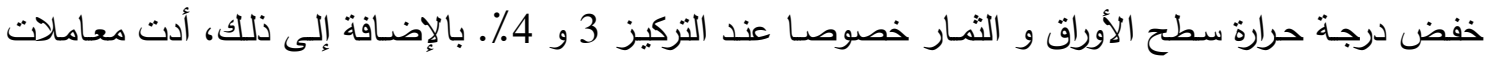
الكاولين الى زيادة المحصول وزنا و عددا و كذلك تحسين جودة الثمار من حيث الحجم، القطر ، الوزن، سمك

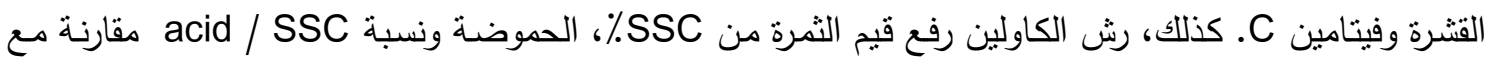
أثجار الكنترول، ولكن لوحظ عدم وجود فروق معنوية بين تركيزات الكاولين على هذه الصفات.

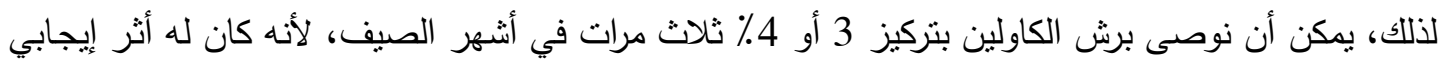
على مقاومة لفحة الثمس وضرر حروق الثمس وزيادة المحصول و تحسين وجودة ثمار أثنجار اليوسفي البلدي. 